NUREG/CR-2279

SAND81-1732

R7

Printed March 1982

\title{
Water Release From Heated Concretes
}

Lawrence A. Kent

Prepared by

Sandia National Laboratories

Albuquerque, New Mexico 87185 and Livermore, California 94550

for the United States Department of Energy

under Contract DE-AC04-76DP00789

\section{Prepared for}

U. S. NUCLEAR REGULATORY COMMISSION 


\section{DISCLAIMER}

This report was prepared as an account of work sponsored by an agency of the United States Government. Neither the United States Government nor any agency Thereof, nor any of their employees, makes any warranty, express or implied, or assumes any legal liability or responsibility for the accuracy, completeness, or usefulness of any information, apparatus, product, or process disclosed, or represents that its use would not infringe privately owned rights. Reference herein to any specific commercial product, process, or service by trade name, trademark, manufacturer, or otherwise does not necessarily constitute or imply its endorsement, recommendation, or favoring by the United States Government or any agency thereof. The views and opinions of authors expressed herein do not necessarily state or reflect those of the United States Government or any agency thereof. 


\section{DISCLAIMER}

Portions of this document may be illegible in electronic image products. Images are produced from the best available original document. 


\section{NOTICE}

This report was prepared as an account of work sponsored by an agency of the United States Government. Neither the United States Government nor any agency thereof, or any of their employees, makes any warranty, expressed or implied, or assumes any legal liability or responsibility for any third party's use, or the results of such use, of any information, apparatus product or process disclosed in this report, or represents that its use by such third party would not infringe privately owned rights.

Available from

GPO Sales Program

Division of Technical Information and Document Control

U.S. Nuclear Regulatory Commission

Washington, D.C. 20555

and

National Technical Information Service

Springfield, Virginia 22161 


$$
\text { NUREG/CR--2279 }
$$

DE82 015196

\author{
NUREG/CR-2279 \\ SAND81-1732 \\ Water Release from Heated Concretes \\ Lawrence A. Kent \\ Division 1537 \\ Sandia National Laboratories \\ Albuquerque, New Mexico 87185
}

\title{
Abstract
}

Water release from three concretes as a function of temperature has been determined experimentally. Limestone concrete releases more water at a moderate temperature than do magnetite or basalt concretes. The amount of water in the concretes is $6.2 \%, 6.3 \%$, and $5 \%$ by weight for 1 imestone, basalt and magnetite concretes respectively, All of the concretes show three distinct weight losses as a function of temperature. By $450 \mathrm{~K}, 52$ to 75 percent of the water is lost--all of the water is lost by $750-800 \mathrm{~K}$. 


\section{TABLE OF CONTENTS}

Introduction

Characterization of Concretes

Limestone

$1-2$

Basalt

$2-3$

Magnetite

Experimental Results

Weight Losses

Concrete Characterization Results

$4-5$

Discussion of Results

$5-7$

Conclusions

References

APPENDIX A: Chemical Compositions of the Concretes and the Concrete Constituents 
TABLES

TABLE A - Limestone Concrete Mixing Ratio

TABLE B - Basalt Concrete Mixing Ratios

TABLE C - Magnetite Concrete Mixing Ratios

TABLE D - Strength of Concretes

TABLE E

FIGURES

Figure 1 - Iimestone Concrete, Water Loss as a Function of Temperature

Figure 2 - Limestone Concrete, Percent Water Loss as a Function of Temperature

Figure 3 - Basalt concrete, Water Loss as a Function of Temperature

Figure 4 - Basalt Concrete, Percent water Loss as a Function of Temperature

Figure 5 - Magnetite Concrete, Water Loss as a Function of Temperature

Figure 6 - Magnetite Concrete, Percent Water Loss as a Function. of Temperature

Figure 7 - Water Release Specimens 15

Figure 8 - Magnetite Concrete, Thermogravimetric Analysis 16

Figure 9 - Magnetite Concrete, Thermogravimetric Analysis 17 


\section{Introduction}

Several types of concrete are used in the construction of nuclear reactors. Under certain postulated accident conditions, these concretes will experience temperatures beyond those encountered in normal operations. Concretes lose their mixing water when heated. This water is then free to react with other components of the reactor or to act as a source of pressure in the reactor containment. For example, molten sodium is used to cool the nuclear core of a fast breeder reactor. The attack of concrete by sodium is described in Reference 1. The molten sodium reacts with the water that is released from the concrete and forms hydrogen gas by reactions such as:

$$
\begin{gathered}
\mathrm{Na}+\mathrm{H}_{2} \mathrm{O} \rightarrow \mathrm{NaOH}+1 / 2 \mathrm{H}_{2} \\
2 \mathrm{Na}+\mathrm{H}_{2} \mathrm{O} \rightarrow \mathrm{Na}_{2} \mathrm{O}+\mathrm{H}_{2}
\end{gathered}
$$

Therefore, the amount of water thermally driven from the concrete is important in analyzing sodium-concrete interactions. Several computer codes $(2,3)$ exist that calculate the transient release of water from heated bulk concrete. However, these codes require a knowledge of the water available. To define the amount of water released at a given temperature, samples of basalt, limestone and magnetite concrete were obtained for water release experiments. Samples were also obtained to test for strength, specific gravity, absorption and voids in hardened concrete per ASTM standards.

\section{Characterization of concretes}

\section{Limestone}

Limestone, being plentiful in the area, is proposed as the aggregate for the structural concrete in the Clinch River Breeder Reactor (CRBR). This particular limestone was $95 \%$ calcite, $\mathrm{CaCO}_{3}$.

* The basic chemical composition of a number of concretes was determined by D. A. Powers. These compositions are given in Appendix $A$. 
Samples of CRBR limestone concrete were made in accordance with the mix proportions established per ERDA (now DOE) letter dated $7 / 12 / 76 .(4)$ The mix ratio is given in Table $A$.

TABLE A

Limestone Concrete Mixing Ratio

$$
\left(\mathrm{Kg} / \mathrm{m}^{3}\right)
$$

$\begin{array}{lc}\text { Cement } & 278.6 \\ \text { Water** } & 144.6 \\ \text { Sand } & 771.2 \\ \text { Aggregate } & 1079.4 \\ \text { Flyash } & 47.4 \\ \text { Air Entraining Agent } & 0.51 \\ \text { Water Reducing Agent } & 0.51\end{array}$

\section{Basalt}

Basalt concrete was used as a structural material in the Fast Flux Test Facility (FFTF). Basalt is made up largely of silicon dioxide, $\left(\mathrm{SiO}_{2}\right)$, calcium oxide $(\mathrm{CaO})$ and aluminum oxide $\left(\right.$ A.). $\left.{ }_{2} \mathrm{O}_{3}\right)$.

Samples of basalt concrete were made from "fine" aggregate (9.5 $\mathrm{mm}$ mesh) per ASTM C-33(5) and ACI-613-54 ${ }^{(6)}$. The mix ratio is given in Table $B$. The mix ratio was obtained from the FFTF project office. (7)

**The water content listed in the tables for each of the three concretes includes the water contained in the sand and aggregate as well as the added mix water. 
TABLE B

Basalt Concrete Mixing Ratios

$$
\left(\mathrm{Kg} / \mathrm{m}^{3}\right)
$$

Cement

258.7

Water

141.2

Sand $\left(\mathrm{SiO}_{2}\right)$

834.2

Aggregate

1073.3

Pozzalan

46.0

Air Entraining Agent

0.48

Water Reducing Agent

0.48

\section{Magnetite}

Magnetite concrete is found in the Fast Flux Test Facility (FFTF) reactor cavity region. This high density concrete is used as a "biological shield". Magnetite concrete, of course, contains largely the iron oxide, magnetite, $\mathrm{Fe}_{3} \mathrm{O}_{4}$ i Magnetite concrete was made per ASTM C-33 ${ }^{(5)}$ and ACI-613-54(6). The mix ratio is given in Table $C$ and was obtained from the FFTF project office. (7)

TABLE C

Magnetite Concrete Mix Ratios

$$
\left(\mathrm{Kg} / \mathrm{m}^{3}\right)
$$

Cement

water

Sand (Magnetite)

Aggregate (Magnetite)

Water Reducing Agent
384.2

189.2

1373.4

1757.6

0.94

For both the basalt and magnetite concretes, the aggregate and sand were purchased from the same commercial source that supplied construction materials for the FFTF. 
Experimental Results

\section{Weight Losses}

The samples for dehydration studies were initially in the saturated, surface dry condition. Sample sizes ranged between 600 and 1200 grams. The specimens were cut (water/cooled) from the center portion of the cast cylinders and were air dried and stored at 100 percent relative humidity for at least 90 days. The specimens were used in the bulk form - not powdered. The samples were measured, weighed and then heated to an initial selected temperature. The samples were maintained at temperature until the difference between values obtained from two successive weighings was less than $0: 5$ percent of the lowest weight obtained ${ }^{(8)}$. The temperature was then raised to the next selected value.

The weight change of limestone concrete attributable to water loss on heating is shown in Figure $l$ and the percentage change of initial water in Figure 2. Similar curves for basalt concrete are given in Figures 3 and 4 and for magnetite concrete in Figures 5 and 6 .

In the water loss as a function of temperature figures, the free water (evaporable water) $(11)$ is shown to be released relatively quickly between 300 to $350 \mathrm{~K}$. A slow release is evident then until a temperature of about $670 \mathrm{~K}$ is reached from which point the remaining water (chemically constituted water) (11) is more rapidly released. The water released between $350 \mathrm{~K}$ to $670 \mathrm{~K}$ is defined in this report as, "chemically combined water." This water is more tightly bound than the free water but not as tightly bound as the chemically constituted water.

A typical basalt concrete water release specimen before an experiment is shown in Figure $7 \mathrm{~A}$. Figure $7 \mathrm{~B}$ shows two 1 imestone concrete specimens after they were subjected to a temperature of about $970 \mathrm{~K}$ and allowed to rehydrate at room tcmperature.

concrete Characterization Results

Samples were also taken of all three concretes and stored at 100 percent relative humidity for compression tests at 7,28 , and 90 days. These results are shown in Table $D$. 
TABLE D

Strength of concretes

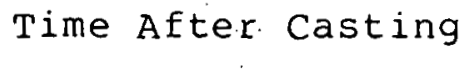

Strength

(Days)

MPa psi

$( \pm 2$ percent)

Limestone

$\begin{array}{rrrr}7 & & 25.9 & 3767 \\ 28 & & 31.6 & 4590 \\ 90 & & 35.2 & 5100 \\ & \text { Basalt } & & \\ 7 & & 12.9 & 1875 \\ 28 & & 19.8 & 2865 \\ 90 & & 27.1 & 3926 \\ & & & \\ 7 & & & 3468 \\ 28 & & 40.9 & 5854 \\ 90 & & 48.0 & 6962\end{array}$

The results of the tests for specific gravity, absorption, and voids in hardened concrete as per ASTM $C 642-75^{(8)}$ are shown in Table E.

TABLE E

\section{Sample}

Absorption

Specific gravity

Volume of permeable voids
(음)

(욤)

$\frac{\text { Basalt }}{7.6}$

16.9

Limestone
6.1
2.6
13.8

13.8
Magnetite

4.6

4.0

15.7

A thermogravimetric analysis ${ }^{(9)}$ (TGA) was conducted on a $54 \mathrm{mg}$ sample of powdered magnetite concrete. The results of this analysis are shown in Figures 8 and 9 .

\section{Discussion of Results}

Weight losses from concrete, as a function of temperature, consist of three events: 1) loss of evaporable water (300 to 350 K), 2) loss of chemically combined water (350 to $670 \mathrm{~K}$ ), and 
3) loss of chemically constituted water (670 to $750 \mathrm{~K}$ ).

In observing the curves of concrete water release as a function of temperature, one point is significant - limestone concrete releases more water at moderate temperatures than do magnetite or basalt concretes. For example, from Figure 1 it is seen that limestone concrete has lost about $80 \mathrm{~kg} / \mathrm{m}^{3}$ of water at $350 \mathrm{~K}$. Figures 3 and 5 show that basalt and magnetite concrete have lost about 30 and $60 \mathrm{~kg} / \mathrm{m}^{3}$ of water, respectively, at $350 \mathrm{~K}$. Water is found in concrete primarily in the cementitious phase. Each of the three types of concrete used the same cement, however, the limestone concrete had flyash added to retard the curing rate while the basalt and magnetite concretes used pozzalan.

The results found in these experiments are in general agreement with the results in reference 3. The data from reference 3 shows the quantity of water released was greater than the mixing water. possible explanations are that the 6"xl2" cylinders picked up additional water from the humid environment in which they were stored or that the moisture contained in the sand and aggregate was not included in the mixing water total. The former reason seems unlikely.

The strength of concrete has a large statistical variation both between types of concretes and between different samples of the same concrete. This is partly so because concrete is a composite, brittle material. The main. contributors to concrete strength are the types of sand, aggregate and cement used as well as the water to cement ratio and the length of cure. The results of the strength measurements reported in the table are typical of their types and, therefore, lend support to the assumption that the results of these water release tests are representative of bulk construction concretes.

The TGA curves and the water release curves compare well. The curves have the same shape but are shifted along the $x$-axis. This is to be expected since thermal decomposition reactions typically obey kinetic expressions that describe the mass loss in terms of time, temperature and the amount of decomposing material present in the sample. The rate of mass loss is a function of both time and 
temperature and consequently heating rate which was $10^{\circ} \mathrm{C} / \mathrm{min}$ in the TGA experiments. Varying heating rates will produce different amounts of mass loss at given temperatures. The magnitude of the difference depends on specific features of the decomposition reaction in question. As a rule, higher heating rates yield lower mass loss at a particular temperature as was seen in this study.

\section{Conclusions}

The term "concrete" describes a class of materials rather than a single material. The properties found within this class of materials can vary widely and depend on many factors. This study has shown that water release on heating follows this pattern. At the start of the study, this result was not anticipated--that one type of concrete would release more of its water under equilibrium conditions and at a given temperature than another type of concrete. 


\section{References}

1. Advanced Reactor Safety Research Quarterly Report, April-June 1978, NUREG/CR-0469, SAND78-2001, pg. 106, Sandia Labs, 1979.

2. J.V. Beck \& R.L. Knight, "User's Manual for USINT - A Program for Calculating Heat and Mass Transfer in Concrete subject to High Heat Fluxes," SAND79-1694, Sandia Labs, 1980.

3. A.K. Postma, J.D. McCormack \& J.A. Schur, "A Study of Water and Gas Release from Heated Concrete," HEDL TC-996, Hanford Engineering Development Lab., 1977.

4. Letter, Anthony R. Buhl, CRBRPO, to R.P. Denise, NRC, July 12 , 1976

5. "Standard Specifications for Concrete Aggregate", (American Society for Testing and Materials, C-33)

6. "Recommended Practice for Selecting proportions for concrete", (Americal Concrete Institute, 613-54)

7. Letter, D.E. Simpson, HEDL, to J.G. Boyer, Sandia, December 15, 1977 .

8. "Specific Gravity, Absorption, and Voids in Hardened Concrete", (Americal Society for Testing and Materials, C642-75)

9. Advanced Reactor Safety Research Quarterly Report, April-June, 1980. NUREG/CR-1594 (2of 4), SAND80-1646 (2 of 4), MaY, 1981.

10. D.A. Powers and F.E. Arellano, "Large-Scale Transient Tests of the Interaction of Molten Steel with Concrete," NUREG/CR-2282, (SAND81-1753), Sandia Nat'l Labs, 1981.

11. D.A. Powers, et al, "Exploratory Study of Molten Core Material/Concrete Interaction", SAND77-2042, Sandia Labs, Albuquerque, NM, Feb. 1978. 


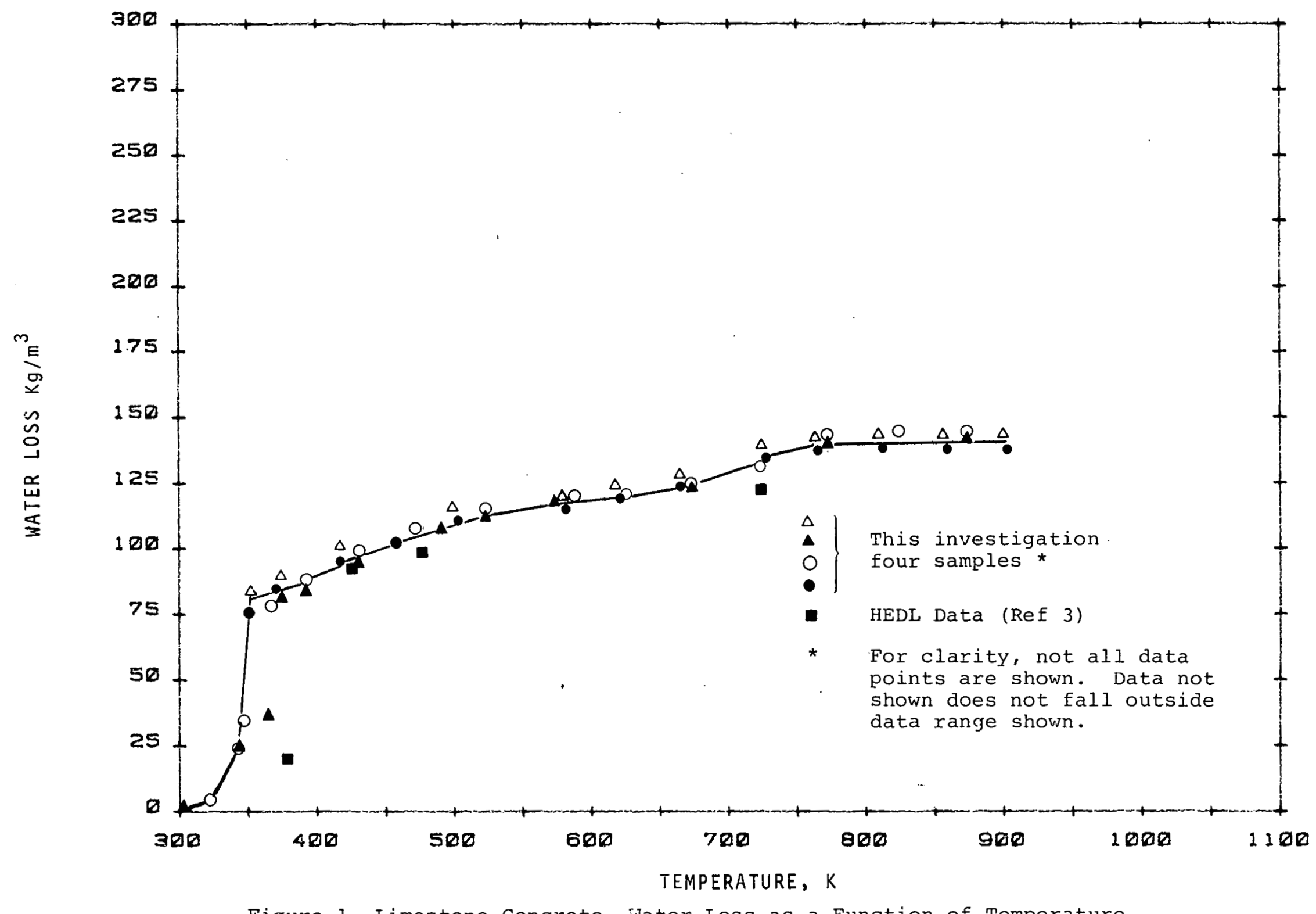

Figure 1 Limestone Concrete, water Loss as a Function of Temperature 


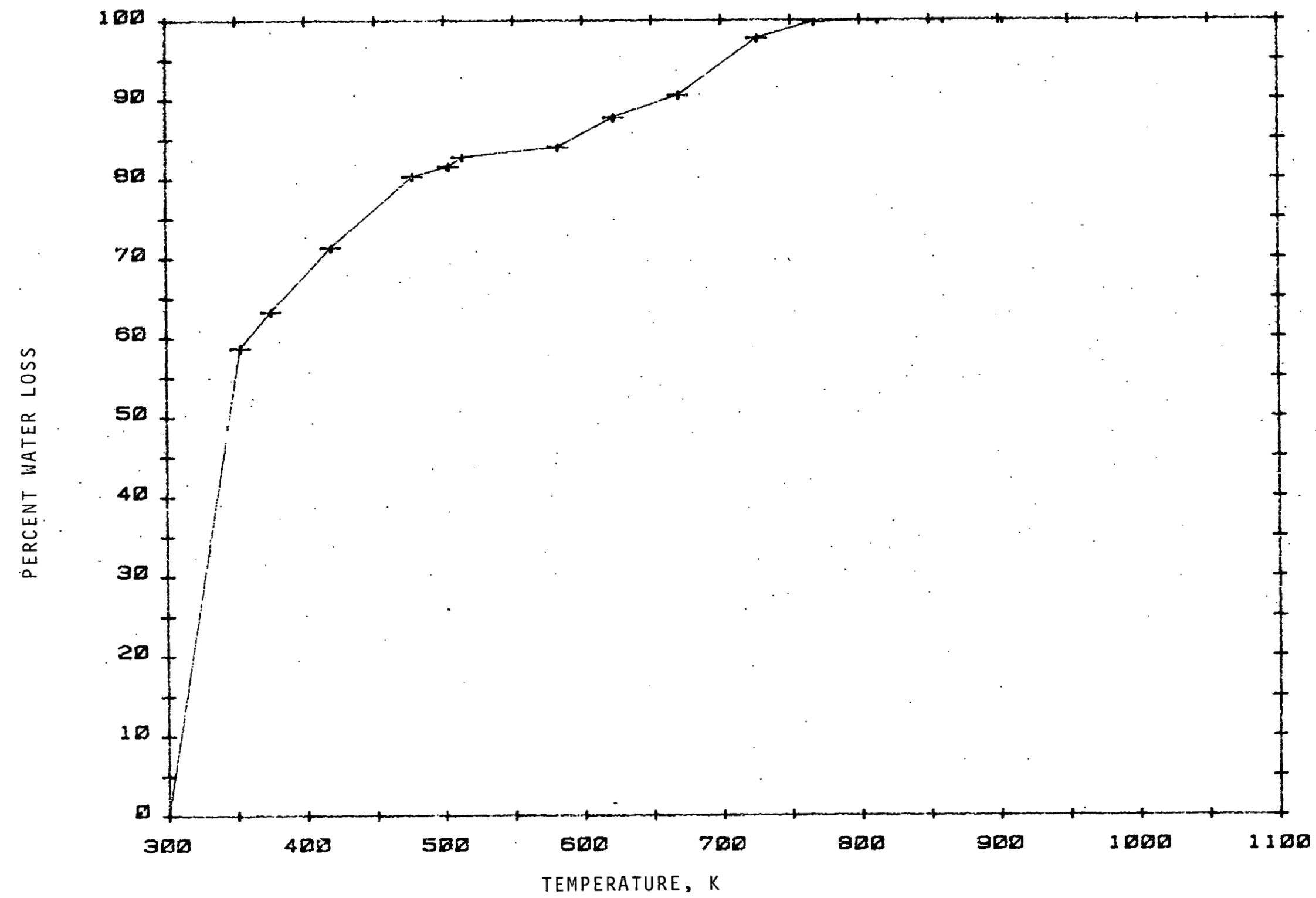

Figure 2 Limestone Concrete, Percent Water Loss as a Function of Temperature 


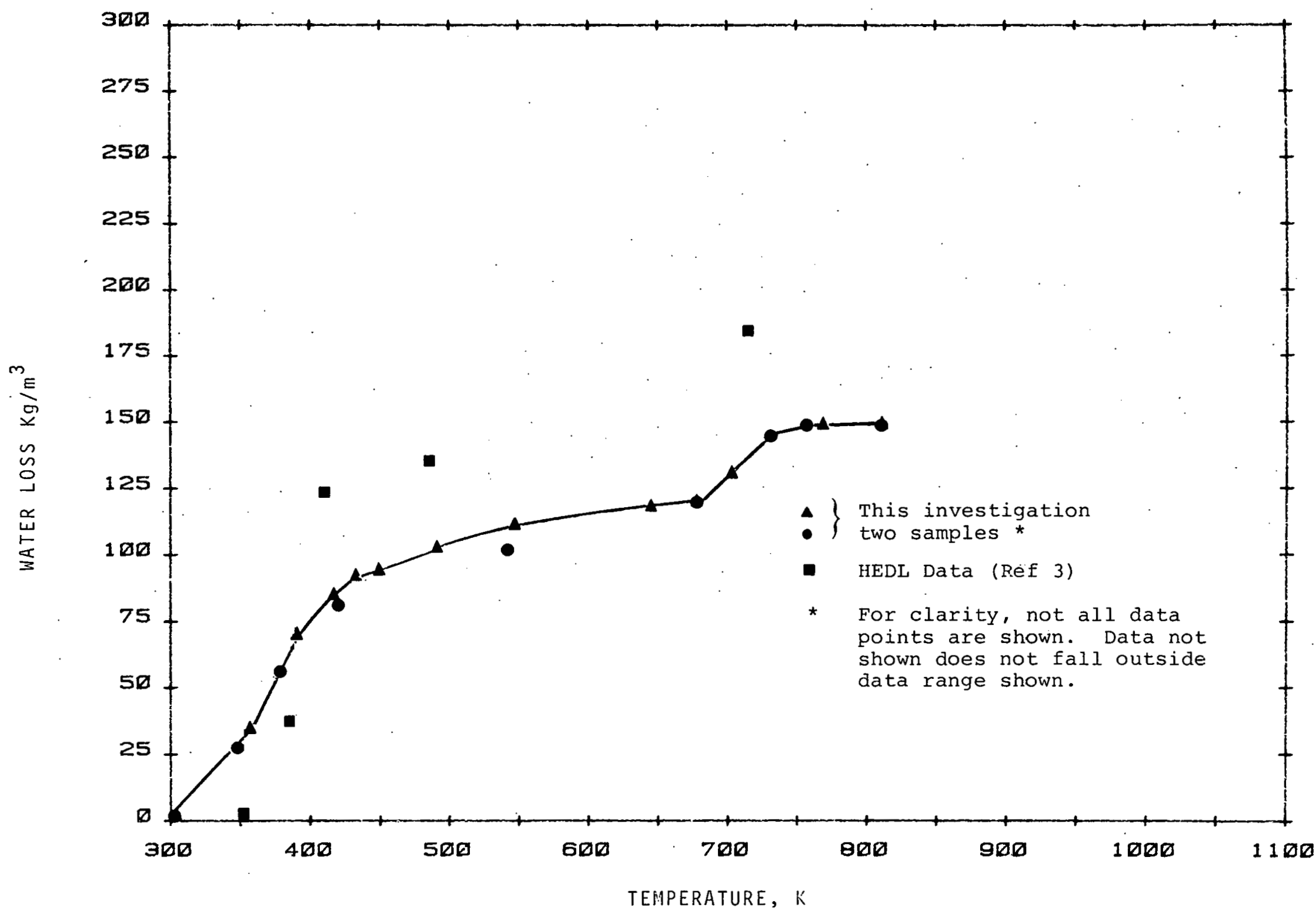

Figure 3 Basalt Concrete, Water Loss as a Function of Temperature 


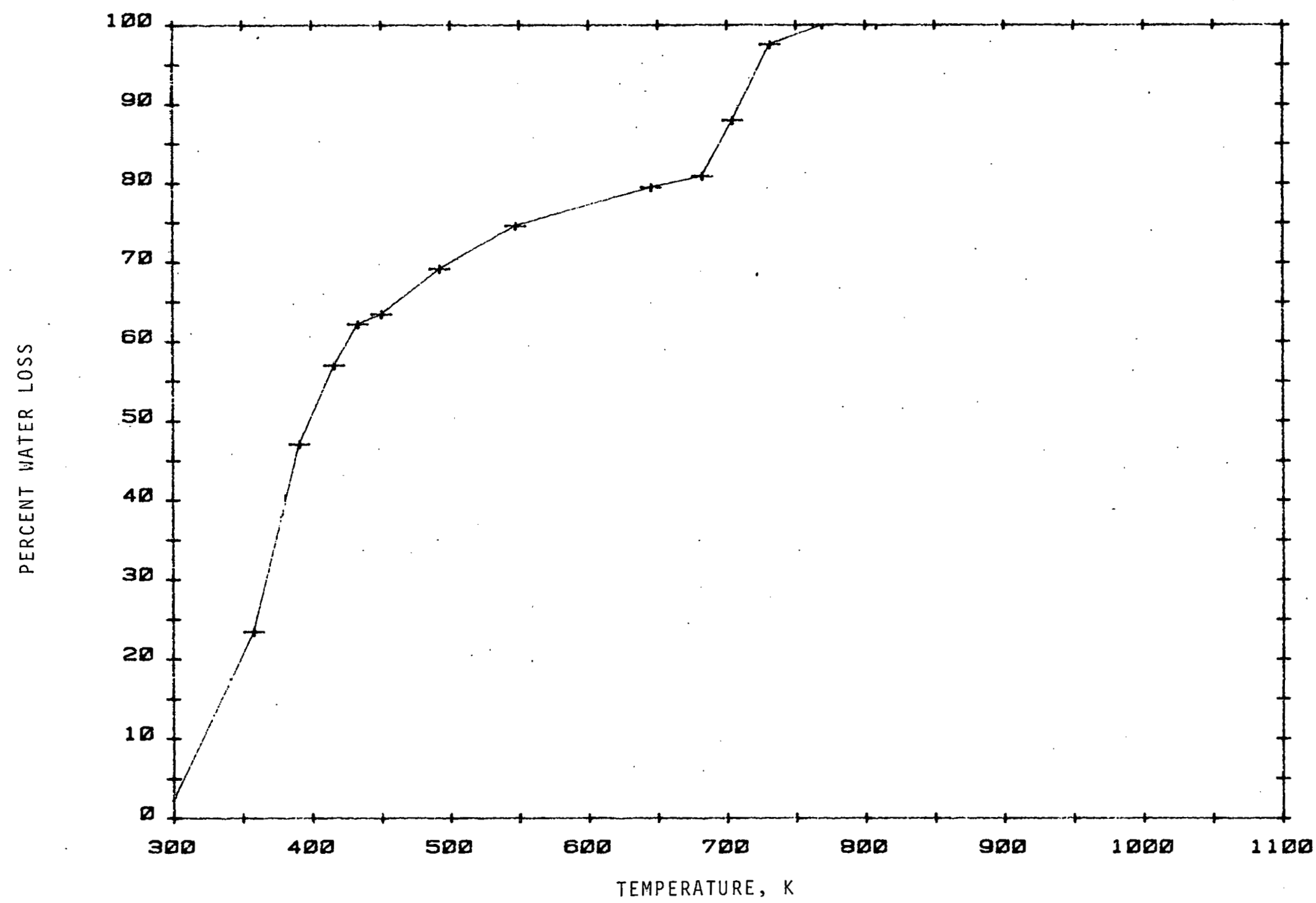

Figure 4 Basalt Concrete, Percent water Loss as a Function of Temperature 


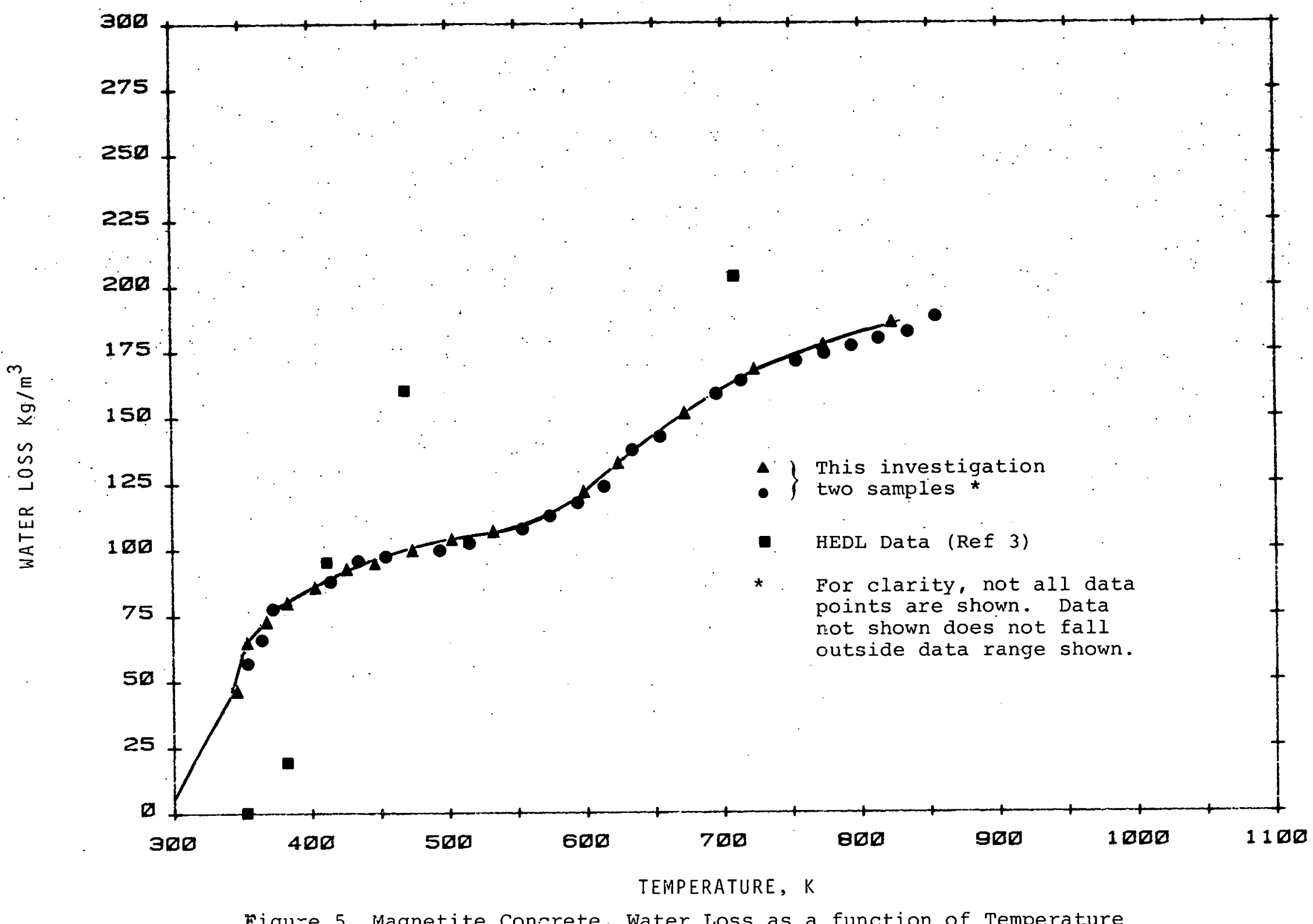

Figure 5 Magnetite Concrete, Water Loss as a function of Temperature 


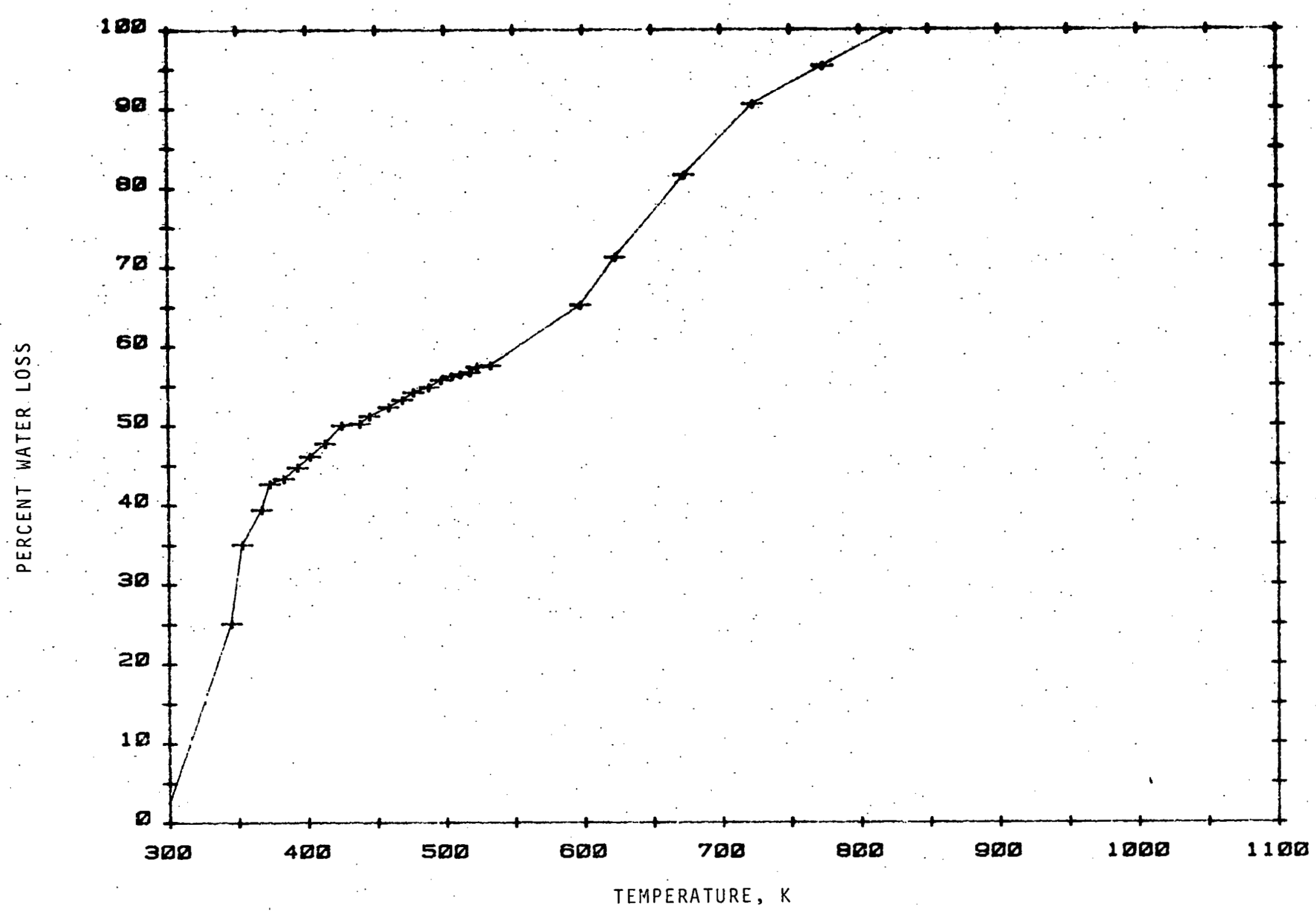

Figure 6 Magnetite Concrete, Percent Water Loss as a Function of Temperature 


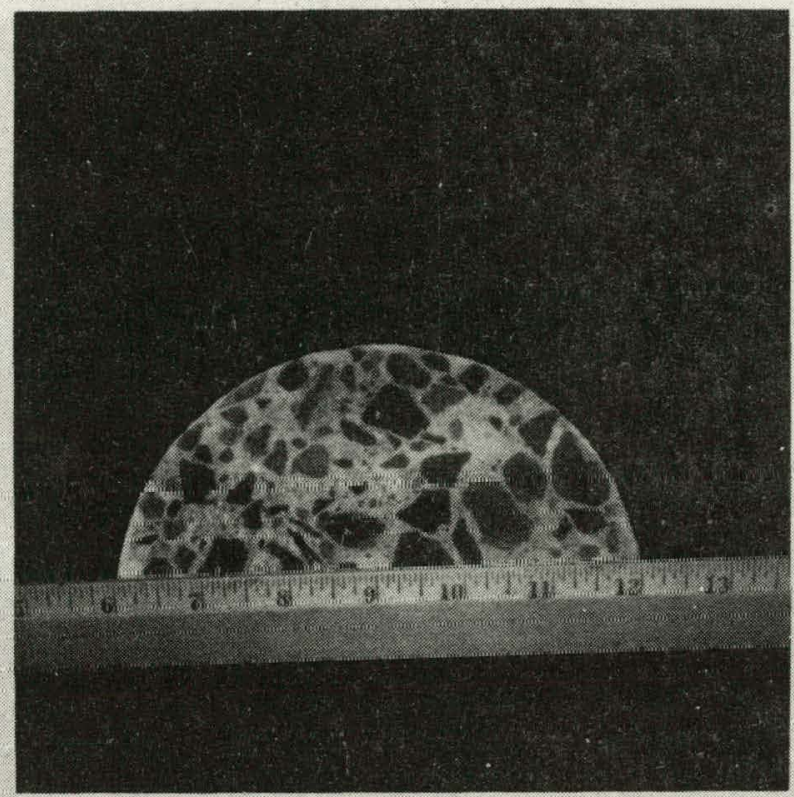

A) Basalt Concrete Specimen Before an Experiment

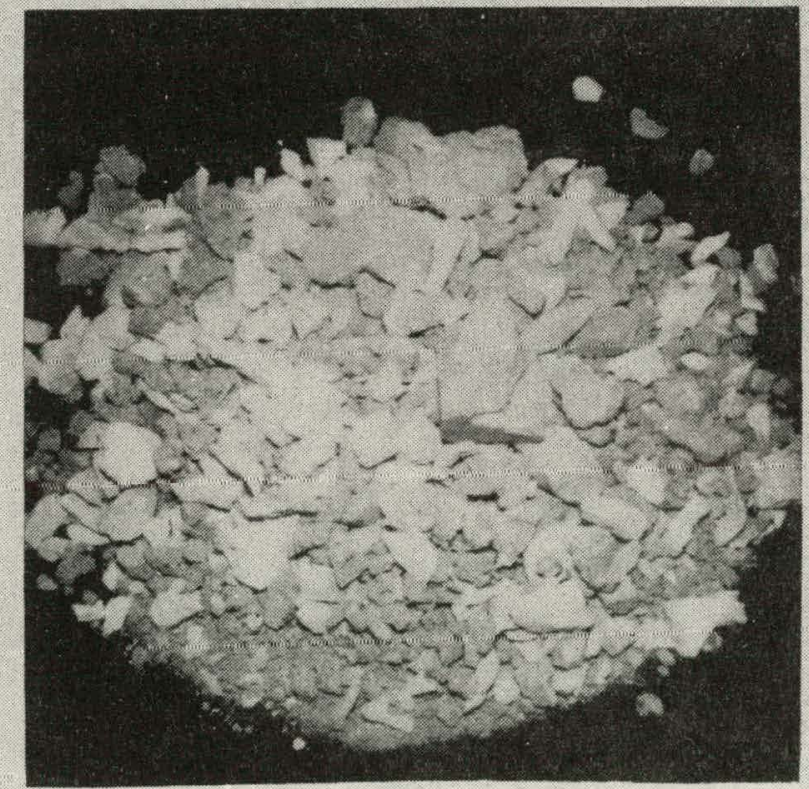

B) Two Limestone Concrete Specimens After Water Release Experiments and Rehydration

Figure 7 Water Release Specimens 


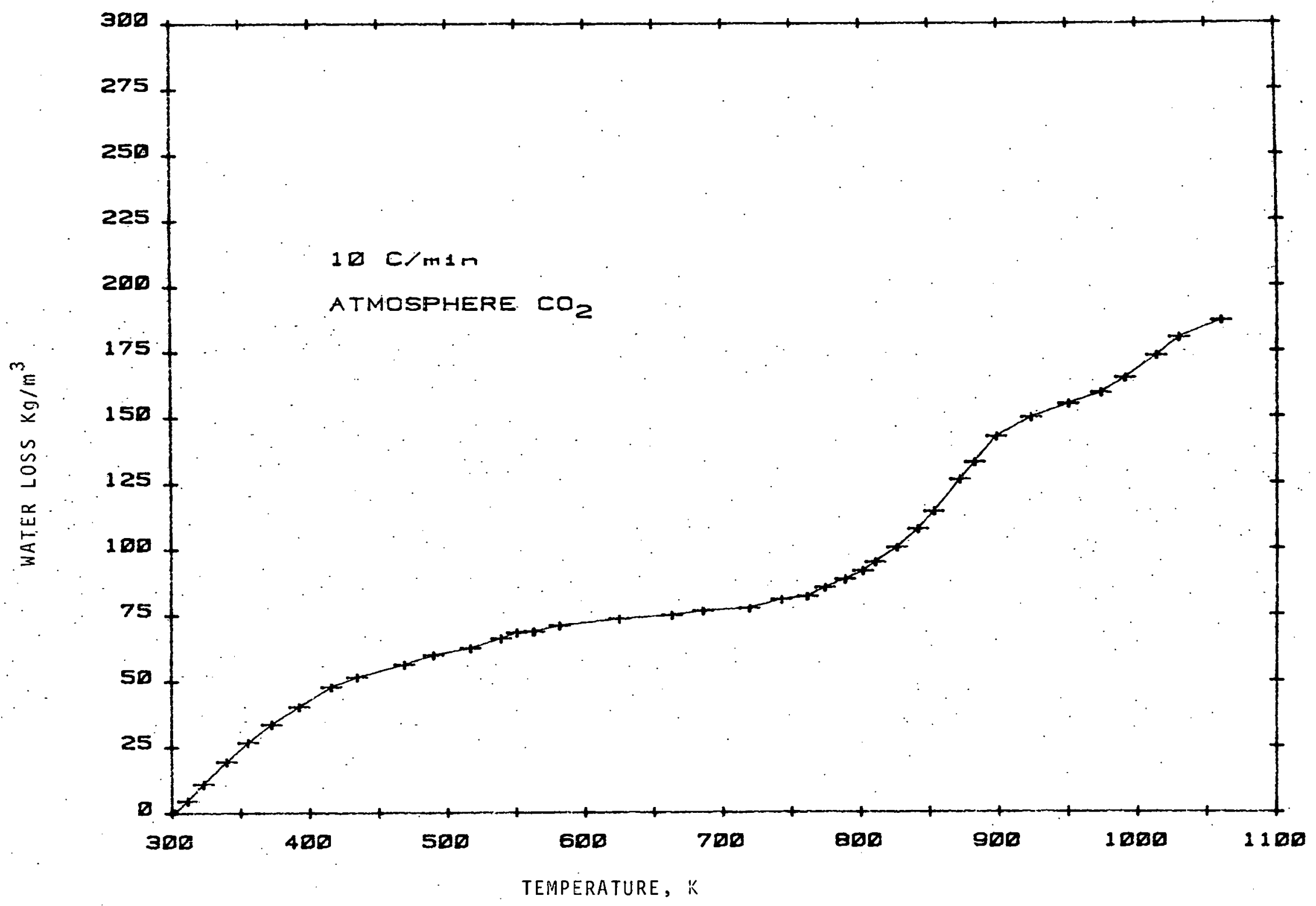

Figure 8 Magnetite Concrete, Thermogravimetric Analysis 


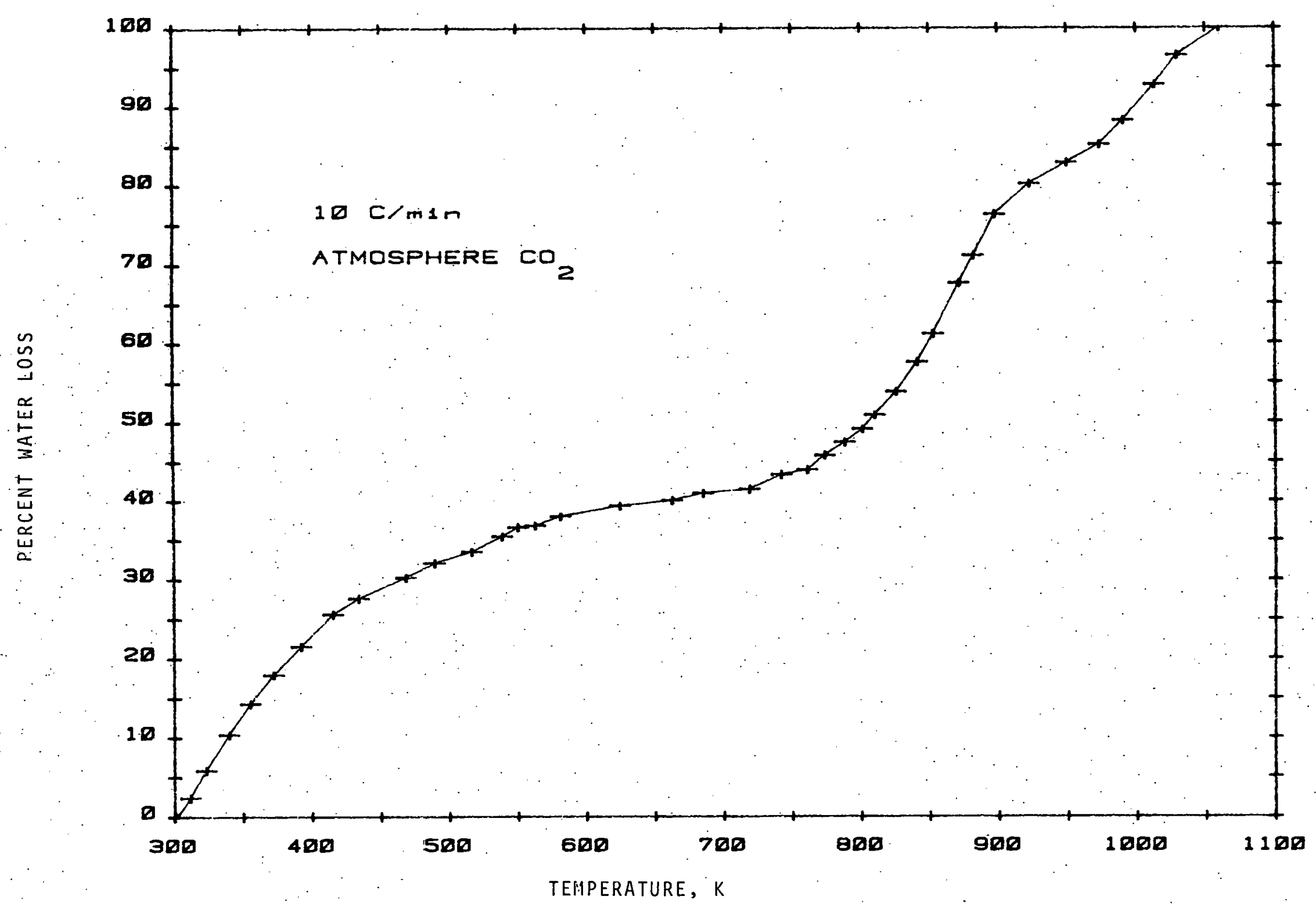

Figure 9 Magnetite Concrete, Thermogravimetric Analysis 


\section{APPENDIX A*}

Chemical Compositicns of the concretes and the concrete constituents

\begin{tabular}{|c|c|c|c|c|c|c|c|c|c|c|}
\hline Oxide & $\begin{array}{l}\text { Tỳpe I } \\
\text { \& II } \\
\text { Cement }\end{array}$ & $\begin{array}{l}\text { Limestone } \\
\text { Aggregate }\end{array}$ & $\begin{array}{c}\text { Limestone/ } \\
\text { Common } \\
\text { Sand } \\
\text { Aggregate }\end{array}$ & $\begin{array}{l}\text { Basaltic } \\
\text { Aggregate }\end{array}$ & Sand & $\begin{array}{l}\text { Fly } \\
\text { Ash } \\
\text { ? }\end{array}$ & $\begin{array}{c}\text { Limestone/ } \\
\text { Common } \\
\text { Sand } \\
\text { Concrete }\end{array}$ & $\begin{array}{l}\text { Basaltic } \\
\text { Concrete }\end{array}$ & $\begin{array}{l}\text { Limestone } \\
\text { Concrete }\end{array}$ & $\begin{array}{l}\text { Expected } \\
\text { Error }\end{array}$ \\
\hline $\mathrm{Fe}_{2} \mathrm{O}_{3}$ & 4.11 & 0.38 & 0.33 & 7.78 & 2.15 & 11.7 & 1.44 & 6.25 & 1.2 & 0.3 \\
\hline $\mathrm{Cr}_{2} \mathrm{O}_{3}$ & 0.011 & 0.012 & ND & 0.06 & 0.042 & 0.022 & 0.014 & ND & 0.004 & 0.01 \\
\hline $\sin 0$ & 0.08 & 0.04 & ND & 0.08 & 0.02. & 0.02 & 0.03 & $N D$ & 0.01 & 0.02 \\
\hline $\mathrm{TiO}_{2}$ & 0.2 & 0.04 & 0.05 & 1.82 & 0.18 & $2: 24$ & 0.18 & 1.05 & 0.12 & 0.04 \\
\hline $\mathrm{K}_{2} \mathrm{O}$ & 0.54 & 0.36 & 0.3 & 7.2 & 2.7 & 3.5 & 1.22 & 5.38 & 0.68 & 0.4 \\
\hline $\mathrm{Na}_{2} \mathrm{O}$ & 0.27 & 0.1 .6 & 0.15 & 1.85 & 1.74 & 0.34 & 0.82 & 1.8 & 0.08 & 0.2 \\
\hline Cao & 63.5 & 47.2 & 45.56 & 6.54 & 1.52 & 1.3 & 31.2 & 8.8 & 45.4 & 1.0 \\
\hline $\operatorname{Mg} 0$ & 1.53 & 0.6 & 0.8 & 9.7 & 0.34 & 1.14 & 0.48 & 6.2 & 5.67 & 0.5 \\
\hline $\mathrm{SiO}_{2}$ & 20.1 & 8.0 & 13.0 & $54: .9$ & 82.8 & 51.2 & 35.7 & 54.73 & 3.6 & 1.5 \\
\hline $\mathrm{AI}_{2} \mathrm{O}_{3}$ & 4.2 & 1.2 & 1.25 & 9.51 & 7.24 & 24.5 & 3.6 & 8.3 & $1.6^{\circ}$ & 0.2 \\
\hline $\mathrm{CO}_{2}$ & ND & 38 & 40 & $<0.02$ & ND & ND & 22 & 1.5 & 35.7 & 1.0 \\
\hline $\mathrm{H}_{2} \mathrm{O}$. & ND & N.D. & ND & 0.1 & 0.1 & 0.3 & 4.8 & 5.0 & 4.1 & 0.5 \\
\hline $\mathrm{SO}_{2}$ & 1.0 & $\therefore \mathrm{ND}$ & ND & ND & ND & ND & $<0.2$ & $<0.2$ & $<0.02$ & 0.2 \\
\hline
\end{tabular}


Acknowledgement

The author wishes to acknowledge

R. U. Acton, Division 1537, for

his helpful discussions and

technical advice. 
Distribution:

U.S. Nuclear Regulatory Commission

( 380 copies for $\mathrm{R} 7$ )

Division of Document Control

Distribution Services Branch

7920 Norfolk Avenue

Bethesda, MD 20014

U.S. Nuclear Regulatory Commission (4)

Division of Reactor Safety Research

Office of Nuclear Regulatory Research

Washington, D.C. 20555

Attn: C. N. Kelber, Assistant Director, Advanced Reactor Safety Research

R. T. Curtis, Chief

Analytical Advanced Reactor Safety Research, ARSR

M. Silberberg, Chief

Experimental Fast Reactor Safety

T. Walker

R. W. Wright

Experimental Fast Reactor Safety

U.S. Department of Energy

Office of Nuclear Safety Coordination

Washington, D.C. 20545

Attn: R. W. Barber

U.S. Department of Energy (2)

Albuquerque Operations office

P.O. Box 5400

Albuquerque, NM 87185

Attn: J. R. Roeder, Director

Operational Safety Division

D. K. Nowlin, Director Special Programs Division

For: C. B. Quinn

D. Plymale

T. Ginsberg

Department of Nuclear Energy

Building 820

Brookhaven National Laboratory

Upton, NY 11973

University of Michigan

Nuclear Engineering Department

Ann Arbor, MI 48104

E. L. Gluekler

General Electric Co.

310 De Guigne Drive

P.O. Box 5020

Sunnyvale, CA 94086 
Distribution (cont)

L. Baker

L. Leibowitz

Argonne Nat'l Laboratory

Argonne, IL 60439

L. Muhlestein

D. Stepnewski

R. Peak

Hanford Engineering Development Lab.

Richland, WA 9935 2

Joel Siegel

CRBRPO

P.O. BOX U

Oak Ridge, TN 37830

D. J. Naus

N. M. Greene

G. F. Flanagan

Oak Ridge Nat'l Laboratory.

Oak Ridge, TN. 37830 .

General Electric Corporation (7)

310 De Guigne Drive

Sunnyvale, CA 94086

Attn: R. A. Meyer, Manager, Analytical Engineering

S. M. Davies, Manager, Conceptual Design Study

J. W. McDonald, Manager, Containment \& Radiological Evaluation

N. W. Brown, Manager, Licensing \& Systems Engineering

M. I. Temme, Manager, Safety Criteria \& Assessments

K. H. Chen, M/C S-54

W. E. Nyer

P.O. Box 1845

Idaho Falls, ID 83401

W. Tarbell

K-Tech Corporation

901 Pennsylvania N.E.

Albuquerque, NM 87110

Projekt Schneller Brueter (4)

Kernforschungszentrum Karlsruhe GMBH

Postfach 3640

D75 Karlsruhe

west Germany

Attn: Dr. Kessler (2)

Dr. Heusener (2) 


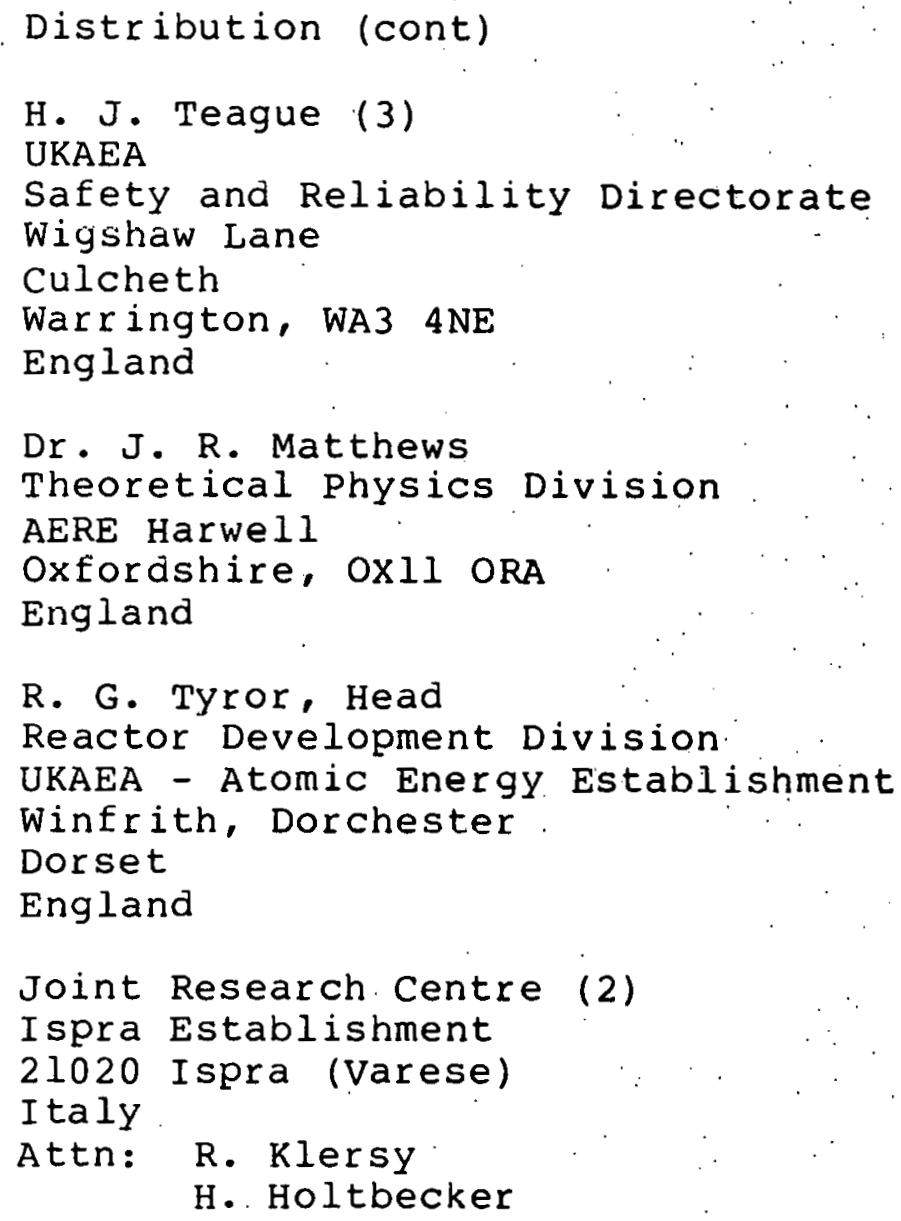

2150 C. B. MçCampbell

3431 B. N. Yates 


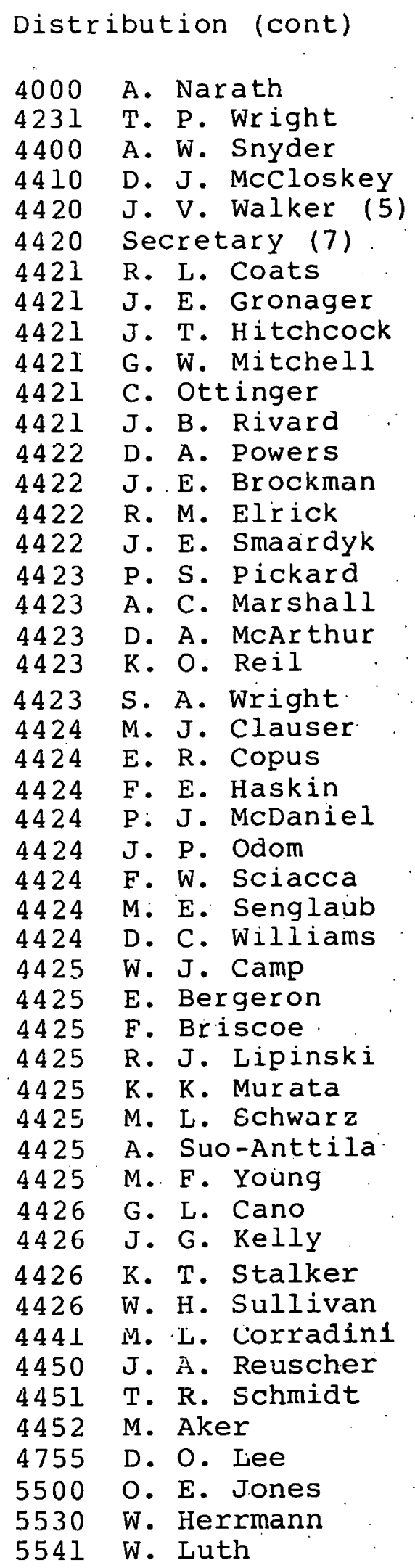


Distribution (cont)

5800 R.'S. Claassen

5820 R. E. Whan

5822 K. H. Eckelmeyer

5830 M. J. Davis

5835 C. H. Karnes

5845 E. K. Beauchamp

5846 R. A. Sallach

5846 W. A. Averill

8214 M. A. Pound

3141 L. J. Erickson (5)

3151 W. L. Garner (3)

For DOE/TIC (Unlimited Release)

3154-3 C. H. Dalin (25)

For: NRC Distribution to NTIS 



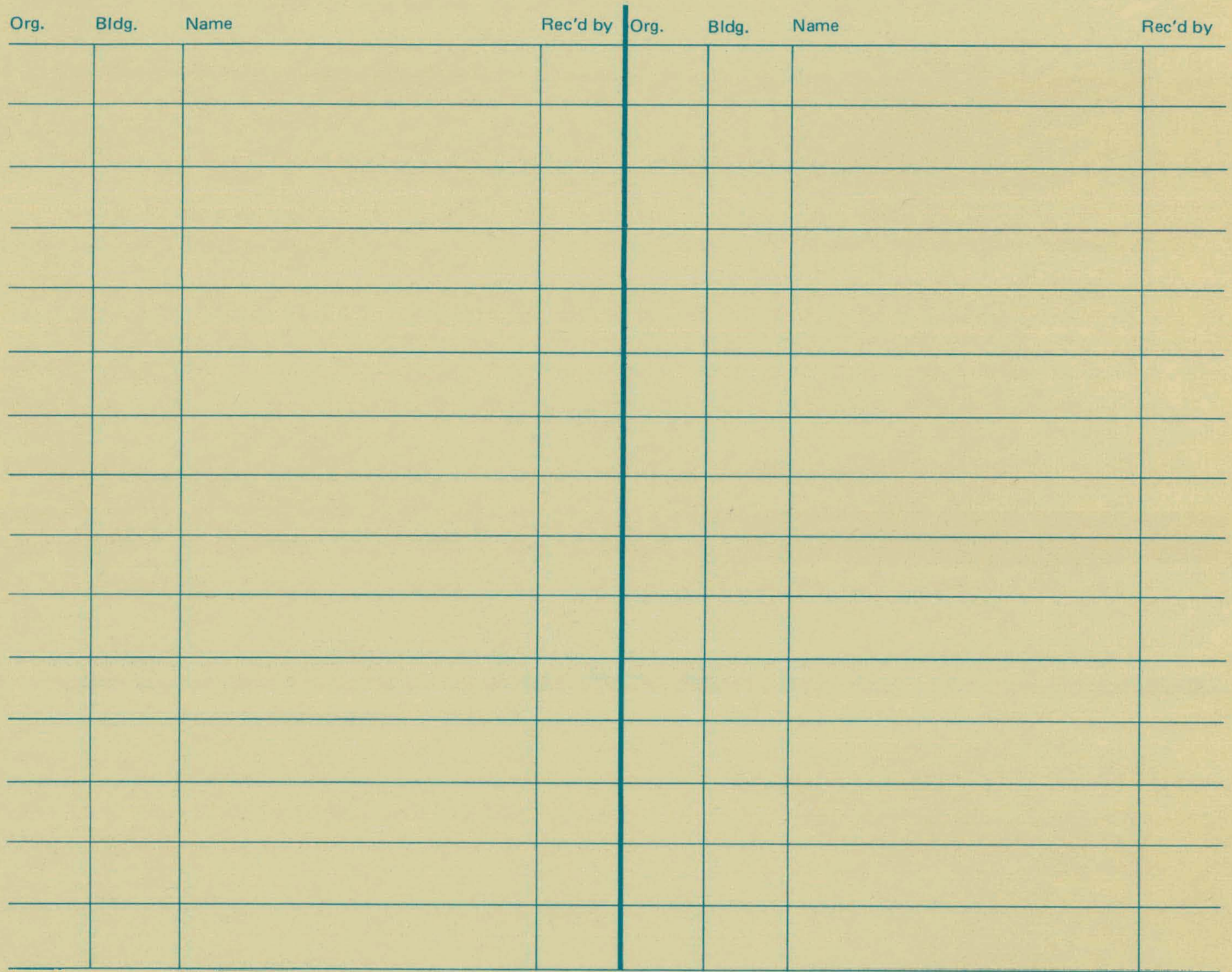

